\title{
Lichen Sclerosus et Atrophicus
}

National Cancer Institute

\section{Source}

National Cancer Institute. Lichen Sclerosus et Atrophicus. NCI Thesaurus. Code C26817.

A chronic inflammatory process affecting the skin. It is characterized by the presence of white, indurated plaques, epidermal atrophy, and fibrosis of the upper dermis. It usually appears in the vulva and penis. 